\title{
Legal Representative of the Sponsor
}

National Cancer Institute

\section{Source}

National Cancer Institute. Legal Representative of the Sponsor. NCI Thesaurus. Code C51832.

An individual with expertise in the law who provides legal counsel and representation to the individual, company, institution, or organization taking responsibility for the initiation, management, and financing of a study. 